\title{
Effect of diets differing in fibre content fed during the early growth stage of pigs on subsequent energy and nutrient digestibility*
}

\author{
G. Skiba ${ }^{1}$, St. Raj, D. Weremko and H. Fandrejewski \\ The Kielanowski Institute of Animal Physiology and Nutrition, Polish Academy of Sciences \\ 05-110 Jabłonna, Poland
}

\begin{abstract}
The digestibility of energy and nutrients was determined in piglets weaned at $10 \mathrm{~kg}$ and fed a standard diet B, with a fibre (F) content of $37.9 \mathrm{~g} / \mathrm{kg}$, or diets with the F content increased to 53.5, 60.6 and $76.4 \mathrm{~g} / \mathrm{kg}$ (diets GM10, GM15 and GM20, respectively). The diets were fed until 25 $\mathrm{kg} \mathrm{BW}$ and then were replaced by diet B fed to all pigs for 14 days. During the last 5 days the digestibility of diet $\mathrm{B}$ was measured in pigs previously fed on diets with increased F contents. In diets with a higher F content, the digestibility of energy and nutrients, except F, was lower, whereas the digestibility of $\mathrm{F}$ was higher than in diet $\mathrm{B}$. Consequently, the energy value of these diets was lower by 0.9-1.1 MJ ME. The energy and nutrient digestibilities of diet B fed after diets with a higher $\mathrm{F}$ content were not affected by the preceding diet except NDF and F digestibilities, which were digested better. The energy value of diet B fed to pigs pre-fed on high-fibre diets was from 0.15 to $0.21 \mathrm{MJ} \mathrm{ME}$ greater as compared with that of diet B fed continuously.
\end{abstract}

KEY WORDS: piglets, compensatory growth, fibre, digestibility

\section{INTRODUCTION}

Feeding high fibre diet decreases the growth rate of pigs and for this reason is often applied to induce compensatory growth of pigs fed on a standard diet during the following period.

The aim of the study was to evaluate the effects of feeding weaned piglets on diets with an increased fibre content on the digestibility of energy and nutrients

\footnotetext{
${ }^{*}$ Supported by The European Commission (the V Framework Programme) within Project "Sustainability in the production of pork with improved nutritional and eating quality using strategic feeding in out-door production”. Contract No. QLK5-CT-2000-00162

${ }^{1}$ Corresponding author: e-mail: g.skiba@ifzz.pan.pl
} 
of a standard commercial diet fed later. The digestibility of diets differing in fibre content was also determined.

\section{MATERIAL AND METHODS}

The experiment comprised two periods: feeding standard and experimental diets from 10 to $25 \mathrm{~kg}$ body weight and feeding a standard diet during the following 14 days.

Twenty piglets with a $10 \mathrm{~kg}$ mean BW were allotted to four groups and until 25 $\mathrm{kg}$ BW were fed ad libitum on a standard commercial diet B (12.3 MJ ME, $201 \mathrm{~g}$ crude protein, 37.9 g crude fibre per $\mathrm{kg}$ ) (group 1), or on diets GM10, GM15 and GM20 with fibre contents increased to $53.5,60.6$ and $76.6 \mathrm{~g} / \mathrm{kg}$ (groups 2, 3 and 4 , respectively). The fibre content was increased by mixing diet B with 10,15 or $20 \%$ grass meal. At $25 \mathrm{~kg} \mathrm{BW}$, the digestibilities of gross energy, crude protein, ether extract, ash, crude fibre and ADF and NDF fractions of all diets were measured. Thereafter, the pigs from groups fed on diets GM10, GM15 and GM20 were transferred to diet B and after 9 days of feeding, the energy and nutrient digestibilities of diet $\mathrm{B}$ were determined, except in pigs fed diet $\mathrm{B}$ continuously (group 1). In both periods digestibility was determined using $\mathrm{Cr}_{2} \mathrm{O}_{3}$ added to the diets as an indicator. Analysis of variance was performed using Statgraphics version 6.0 Plus software.

\section{RESULTS}

The increased fibre content negatively affected energy and protein digestibility in the first period of the experiment (from 10 to $25 \mathrm{~kg} \mathrm{BW}$ ) and tended also to lower fat digestibility (Table 1). Digestibility of crude fibre was substantially increased due to the increased fibre content, while the effect on digestibility of NDF and ADF was not significant and rather irregular. The content of digestible and metabolizable energy in diets with an increased fibre content was about $1 \mathrm{MJ}$ lower than in the standard B diet.

It was assumed that the digestibility of diet B fed continuously did not change during the relatively short period between two digestibility trials and for group 1 the values found for period 1 are given for period 2 (Table 1). The digestibility of energy and all nutrients except NDF did not differ significantly among the groups. NDF digestibility was higher $(\mathrm{P}<0.001)$ in pigs previously fed high fibre diets, the same tendency was found for crude fibre. The ME content in diet $\mathrm{B}$ fed to pigs previously fed on diet GM10 and GM15 was greater $(\mathrm{P}<0.076)$ by 0.21 and $0.15 \mathrm{MJ}$, while in pigs fed diet GM20 with the greatest fibre concentration, it was slightly lower. 
Table 1. Digestibility of energy and nutrients (\%) and energy value of the diets (MJ/kg diet)

\begin{tabular}{|c|c|c|c|c|c|c|c|c|c|c|}
\hline \multirow[b]{2}{*}{ Group } & \multirow[b]{2}{*}{ Diet } & \multicolumn{7}{|c|}{ Digestibility } & \multicolumn{2}{|c|}{ Energy value } \\
\hline & & $\begin{array}{c}\text { gross } \\
\text { energy }\end{array}$ & protein & $\begin{array}{l}\text { extract } \\
\text { ether }\end{array}$ & ash & $\begin{array}{l}\text { crude } \\
\text { fibre }\end{array}$ & NDF & $\mathrm{ADF}$ & $\mathrm{DE}$ & $\mathrm{ME}$ \\
\hline \multicolumn{11}{|c|}{ Period 1 (10-25 kg BW) } \\
\hline 1 & B & 82.5 & 79.6 & 38.5 & 34.2 & 12.5 & 63.8 & 40.7 & 12.78 & 12.3 \\
\hline 2 & GM10 & 78.0 & 73.2 & 30.7 & 30.0 & 17.8 & 64.6 & 27.6 & 11.89 & 11.4 \\
\hline 3 & GM15 & 76.2 & 72.2 & 32.9 & 36.6 & 16.9 & 68.5 & 31.3 & 11.74 & 11.2 \\
\hline 4 & GM20 & 75.5 & 72.4 & 34.0 & 33.4 & 31.2 & 75.0 & 35.8 & 11.71 & 11.2 \\
\hline & $E M$ & 0.3 & 0.5 & 2.0 & 2.2 & 3.0 & 0.2 & 3.0 & 0.06 & 0.062 \\
\hline $\mathrm{Pv}_{\mathrm{v}}$ & alue & $<0.001$ & $<0.01$ & 0.582 & 0.606 & 0.075 & 0.134 & 0.458 & $<0.001$ & $<0.001$ \\
\hline \multicolumn{11}{|c|}{ Period 2 (14 days) } \\
\hline 1 & $\mathrm{~B}$ & 82.5 & 79.6 & 38.5 & 34.2 & 12.5 & 63.8 & 40.7 & 12.78 & 12.26 \\
\hline 2 & B & 83.8 & 80.7 & 41.4 & 39.6 & 25.6 & 79.5 & 40.3 & 13.03 & 12.47 \\
\hline 3 & B & 83.4 & 80.9 & 39.5 & 37.4 & 23.1 & 77.7 & 39.0 & 12.96 & 12.41 \\
\hline 4 & B & 82.1 & 79.7 & 32.4 & 35.9 & 24.8 & 74.9 & 27.5 & 12.71 & 12.19 \\
\hline & $\mathrm{EM}$ & 0.3 & 0.4 & 2.1 & 0.5 & 1.9 & 1.1 & 3.1 & 0.050 & 0.045 \\
\hline $\mathrm{PV}$ & alue & 0.159 & 0.530 & 0.326 & 0.150 & 0.083 & $<0.001$ & 0.207 & 0.083 & 0.076 \\
\hline
\end{tabular}

\section{DISCUSSION}

A decrease of protein and energy digestibility as a response to an increased fibre content was found also in earlier works (Fernandez et al., 1986). The highest supplement of grass meal to diet B lowered energy and protein digestibility to a greater extent than the $20 \%$ supplement of lucerne meal in the study by Moore et al. (1988), which confirms the effect of fibre source on the digestibility of nutrients related to, among other factors, faster transit along the digestive tract (Jørgensen et al., 1996). Better digestion of crude fibre by pigs from groups 2, 3 and 4 fed the higher fibre diet than group 1 was probably due to more extensive microbial fermentation in the hindgut. However, Fernandez et al. (1986) reported that digestibility of crude fibre in pigs was not greatly influenced by a fibre content ranging from 3 to $11 \%$, while Roth et al. (1985) showed that increasing the crude fibre content significantly decreased its digestibility. These differences might result from different contents of soluble dietary fibre, which stimulates microbial fermentation (Wenk, 2001).

During the period following feeding diets with different fibre contents, the digestibility of energy and nutrients of diet B was not affected by the diet fed previously. A tendency towards better digestion of crude fibre and NDF by pigs fed earlier on diets with a greater fibre content was probably caused by higher activity of microflora in the hindgut. 


\section{REFERENCES}

Fernandez J.A., Jørgensen J.N., 1986. Digestibility and absorption of nutrients as affected by fibre content in the diet of the pig quantitative aspects. Livest. Prod. Sci. 15, 53-71

Jørgensen H., Zhao X.Q., Eggum B.O., 1996. The influence of dietary fibre and environmental temperature on the development of the gastrointestinal tract, digestibility, degree of fermentation in the hind gut and energy metabolism in pigs. Brit. J. Nutr. 75, 365-378

Moore R.J., Kornegay E.T., Grayson R.L., Lindemann M.D., 1988. Growth, nutrient utilisation and intestinal morphology of pigs fed high-fiber diets. J. Anim. Sci. 66, 1570-1579

Roth F.X., Kirchgessner M., 1985. Vergaulichkeit und intestinale Passagerate beim Schwein in Abhängigkeit von Fütterungsniveau und Rohfasergemalt des Futters. Z. Tierphysiol. Tierernähr. Futtermittelk. 53, 254-264

Wenk C., 2001. The role of dietary fibre in the digestive physiology of the pig. Anim. Feed Sci. Tech. 90, 21-33

\section{STRESZCZENIE}

Strawność energii i składników pokarmowych u odsadzonych prosiąt w okresie niedożywiania, spowodowanego zwiększonym pobraniem włókna, oraz podczas realimentacji

Oznaczono strawność energii i składników pokarmowych na prosiętach odsadzonych przy m.c. $10 \mathrm{~kg}$ i żywionych standardową dietą B zawierającą 37,9 g włókna $/ \mathrm{kg}$, oraz dietami zawierającymi 53,5; 60,6 i 76,4 g włókna/kg (odpowiednio dieta GM10, GM15 i GM20). Po osiagnnięciu $25 \mathrm{~kg}$ m.c. wszystkie świnie żywiono dietą B przez 14 dni i w ciagu ostatnich 5 dni oznaczono strawność energii i składników pokarmowych diety B, podawanej świniom żywionym uprzednio dietami o podwyższonej zawartości włókna. Strawność energii i składników pokarmowych, z wyjątkiem włókna, diet zawierających więcej tego składnika była niższa niż diety $\mathrm{B}$, natomiast strawność włókna była wyższa. Wartość energetyczna diet o podwyższonej zawartości włókna była o 0,9 do 1,1 MJ ME niższa niż diety standardowej. Strawność energii i składników odżywczych diety B podawanej zwierzętom żywionym uprzednio dietami o wyższej zawartości włókna nie różniła się, natomiast strawność włókna i frakcji NDF była wyższa. W konsekwencji wartość energetyczna diety $\mathrm{B}$ podawanej tym zwierzętom była o 0,15 do $0,21 \mathrm{MJ}$ wyższa niż diety $\mathrm{B}$, oznaczonej na zwierzętach żywionych nią od odsadzenia. 